\title{
The Image of the Czech Past in the Contemporary Docudrama ${ }^{1}$
}

Czech drama output in the new millennium shows a clear trend towards the documentary, which is increasing in strength as it progressively influences an ever larger group of authors, and over the last few years it has had a fundamental effect on the form of Czech drama as such. Hence instead of purely fictional plots and invented characters, contemporary plays like to resort to historical material and real-life figures from Czech history, whose example authors can use to interpret Czech national identity and thus together recreate it. ${ }^{2}$ Hence it would appear that after many years in which literature has been under the sway of "imaginative" lines of creativity influenced by postmodernism, Czech writing to a large extent is again turning to "authentic" texts, as promoted by literary

1 This study has resulted from the Academic Prize awarded prof. Pavel Janoušek by the Academy of Sciences of the Czech Republic and from long-term support for conceptual development of a research institution; registration number 68378068 .

This work required the use of Czech Literary Bibliography research infrastructure resources (http://clb.ucl.cas.cz).

2 It is also worth mentioning that the increase in interest in twentieth century history, as well as in its reevaluation, is also a trend within contemporary Czech prose, e.g. see the novels Penize od Hitlera (2006) by Radka Denemarková, Vyhnání Gerty Schnirch (2009) by Kateřina Tučková, Všechno je jenom dvakrát by Michal Přibáň and others. 
critic Jan Lopatka and his successors, and based on the personal testimony of an author who usually takes on the role of a kind of guarantor of the veracity of his or her deposition. ${ }^{3}$ Unlike the 199os, however, the current wave of drama has substantially changed its poetics, so that instead of the author's personal testimony, it allows paraphrases or direct quotations from period documents, which often disrupt and modify the traditional dramatic form, to be inserted into the structure of the dramatic works.

This outlined trend, which can be observed in the latest Czech drama texts, goes along hand in hand with theatrical and theatrological trends. The most characteristic aspect in this respect is the development in German-language regions, where considerable attention was being paid to the issue of the "theatre of the real" 4 in connection with existing theatrical practice (see Barton, Irmer et al.). The significant features of this kind of theatre, harking back in some cases to the Piscatorian and Brechtian tradition, include the use of various documentary techniques (including using one's own investigations and research), programmatic bolstering of authenticity, the "truthfulness" and specificity of communication and the political and community dimension of productions; at the same time one speaks of the reaction to the "crisis in mimetic representation," indeed of the social and political turn (Malzacher 11). As a rule, the authors' aim is to go beyond the boundaries of art and to more resolutely enter the public arena, which they believe to be co-determined inter alia by theatrical activities and events.

Together with the repeated trend towards realism, these new Czech plays naturally keep coming back to key sensitive Central European motifs, primarily

3 See Lopatka 1991 and Lopatka 1995.

4 A term that has now caught on in Western European theatrical reflections was used in 2013 by Carol Martin as the title of her monograph. She explains it as follows: "I prefer the phrase 'theatre of the real,' as it both includes and exceeds documentary theatre. The former depends upon verbatim quotation whereas 'theatre of the real' is a larger category and encompasses both theatre about real events and the way real events are conceptualised using diverse means, including fiction clearly identified as such, in the service of non-fiction. Theatre of the real is where the procedures of society are tested, where the role of the artist is to create an aesthetic laboratory for ideas and actions, where the outside world is inside the theatre, and where the role of the spectator is one of a critical analyst assessing the potential of a new and accepted wisdom for the greatest good" (Martin 2015: 42). Elsewhere in the same study Martin adds that " $[t]$ heatre of the real has many names: documentary theatre, verbatim theatre, reality-based theatre, theatre-of-fact, theatre of witness, tribunal theatre, investigative theatre, non-fiction theatre, restored village performances, war and battle re-enactments, and autobiographical and biographical theatre" (Martin 2015: 33). 
reinstating and reviving the polarity within them between history with a capital $\mathrm{H}$ and history with a small h, as the "textbook" historical events inscribe themselves indelibly into the lives of individuals. This polarity is then projected onto the ideological axis of the plays, re-actualizing the conflict based on the social division of "us and them," and in some cases involving an "own/other" dichotomy. Unlike in the past, they no longer just recall historical events from the Nazi occupation and the Communist era, in which totalitarian regime stalwarts stood on one side and resistance fighters or dissidents on the other, but they highlight the more controversial moments, such as the events just after the war associated with the "disorderly" expulsion of the Germans. Hence the ideological axis has suddenly changed to a considerable extent, as the image built up over the years of the peace-loving Czechs finding a just reckoning for the Nazi criminals gradually gives way to a perspective in which the Sudeten Germans take on the role of victims of unjustifiably brutal violence. ${ }^{5}$ The territory of Central Europe as a place between the West and the East, i.e. a multiethnic space where the spheres of influence of two world powers come together, again comes to the centre of attention as it once more becomes primary thematic material in a number of plays. ${ }^{6}$

Czech identity-often set in, and systematically compared with, this Central European context-is thus an object of contemporary literary, theatrological, and artistic reflection, as over the last few years the specific features of the national character have again started to be considered with great interest. Interest has also focused on the question of heroism, which might be summed up as follows:

5 On the other hand, continuity is shown by the image of the Jews, who continue to be perceived as the obvious victims of Nazi and Communist power. In this connection we might e.g. recall the production of Archa naděje, which premiered (in 2015) at the South Bohemian Theatre in České Budějovice. The scriptwriter Martin Vačkář was inspired here by the diary of a direct participant in the exodus of Jews from the Protectorate of Bohemia and Moravia in 1940.

6 The term Central Europe is of course ambiguous-never neutral and if anything "slippery," not only from a geographical, but also from a historical, political, ethnic and cultural etc. standpoint (see Trávníček 243-244); see also the annotated bibliography on the issues surrounding Central Europe). Hence, from a historical perspective one speaks more of various "conceptions of Central Europe," whereas at the most general, rather idealistic level, it was evidently demarcated by Jan Ulrich as "a mental space within changeable borders" (Ulrich 13). With respect to our subject, Jacques Rupnik's retrospectively-based conception of Central Europe is apposite, laconically expressed as it is in the metaphorical title of his book on this territory and the role of the Czech nation within it-Central Europe is like a bird with eyes in the back of its head: on the Czech past and present (2018). 
Does the Czech nation, which has never set great store by heroes, have a supply of heroic individuals who might be made the subject of art works?7 And if we do have any heroes at all, what kind of people were they? What do they share and how do they differ from everybody else?

And let us keep going with some more specific questions: So who are these Czech heroes in contemporary Czech drama? Are they the "founding fathers" led by dear old Masaryk, ${ }^{8}$ the former dissidents around Václav Havel (e.g. Olga Havlová and Věra Čáslavská), or more probably the resistance fighters during the Nazi occupation and under Communist totalitarianism (the Mašín brothers) ${ }^{9}$ Or could it be that the consensual hero who is really worth following does not actually exist? After all, Czech drama also offers countless repulsive anti-heroes who are characteristic of their circumstances (e.g. the first Communist President Klement Gottwald). Such (at least implicit) soul-searching into the Czech past is considered, for example, by Marta Ljubková, editor of an extensive collection of contemporary Czechoslovak dramas Hry na hrdiny (Playing Heroes) to be proof of the revitalized engagement of art and drama as such, which after many years is coming back to politically topical subjects, evoking them by utilizing period documentary material: "Authors are beginning to be inspired by real political events, constructing their plays with authentic material (cf. Iva Klestilovás Má vlast (My Homeland)). From there it is just a small step towards looking for positive heroes, who are only on offer in exceptional cases by contemporary public life. Moreover, the theatre seems to have rediscovered its erstwhile objective: to comment upon current affairs. The effort to address audiences through topical stories, whose relevance to the present day is undeniable and quite natural, has been a kind of reaction to the marginalization of the theatre and culture in general ..." (Ljubková 12).

7 Heroes in Czech drama, contemporary and otherwise, are dealt with in detail by Jaroslav Vostrý and Zuzana Sílová in their monograph České drama a český hrdina (Czech Drama and the Czech Hero) published in 2017.

8 Over the last few years, particularly in connection with the centenary of the establishment of the Republic, productions dealing with figures from the First Republic have been appearing on the stages of several Czech theatres, including Peter Pavlac's Masaryk/Štefánik, which has simultaneously become part of the repertoire at two theatres: Městské divadlo in Zlín and Divadlo Aréna in Bratislava (premiered 2018).

9 The story of the Mašín brothers, which still provokes passionate reactions in Czech circles many years after the fall of Communism, has been dealt with by prose writer Jan Novák in his docu-novel Zatím dobrý (So Far So Good), for which he received the top award in the prestigious Magnesia Litera competition in 2005, as well as by the director Jiří Havelka in his dramatic text Já, hrdina (I, Hero, premiered 2011). 
Of course, docudramas cannot replace real documentaries. Their objective is primarily to recall and reinterpret previous events and historical figures, whose stories are to be experienced, as it were, by readers and audiences, who are then to process them both emotionally and rationally. The documentary material involved in the dramatic structure is meant to give the recipients a sense of authenticity, or in the words of Roland Barthes, to create a "realistic effect" (Barthes 78-81) that is meant to bolster the aesthetic experience and perhaps even the appeal of the message overall. However, this work basically remains fictional, and in most cases this is openly acknowledged, as it "only" adds period documentary elements to its material, including them in its own fictional testimony of the real world. Here we see that inescapable paradox in the relationship between fiction and reality, which can never merge, but only get nearer to or further away from each other, the paradox that broader social changes are interpreted in specific examples, and it is through the fictional testimony that a certain message about the state and the form of the real world is formulated. It is on the basis of this very paradox that the unique genre of the "docudrama" is developing at present. ${ }^{10}$

Obviously, reality gets into the plays in many and varied ways. This always depends on the techniques chosen by dramatists for their texts. In order to briefly sketch out the entire issue in the following pages we shall present several prominent drama works from the recent past, which we shall use to demonstrate the procedures involved in inserting into a drama (i.e. a projected stage fiction) documentary materials, whose task it is to link a fictional testimony to the reader's/audience's world experience and thus ultimately to make it look plausible to the recipient. ${ }^{11}$ This exposition will lead from the format

10 "There are various designations for the documentary 'genre' too: the older term is drama of fact, and more recently docudrama, tribunal drama (a kind of court trial drama) and verbatim drama; the term 'documentary' drama also overlaps with the concept of the political play, as well as other 'new dramatics' genres.... However, it differs from them in its rejection of fiction, its emphasis on factuality and facts and the relatively large para-dramatic element (in this case by accepting phenomena from reality and their inclusion within a dramatic or theatrical framework)" (Jungmannová 36).

11 "Like the creators of realist drama, the creators of 'documentary' plays endeavour to come as close as possible to reality, or to utilize the situation to make the reality speak for itself, so that they create their plays in the same way as they undertake precise research: seeking out various real-life material, recording opinions, memories and experiences on a dictaphone, including media announcements and the results of various sociological procedures, such as interpreted communications and texts from social networks and the like. Hence, a 'documentary' play tends to be journalistic or investi- 
of the traditional autobiographical play with elements of situation comedy (Zázrak v černém domě, Miracle at the Black House) and biographically-based dramas (Olga, Věra), texts simulating trials ("tribunal drama": Horáková-Gottwald, Horáková vs Gottwald, S naději i bez ní, With and Without Hope), to montages and collages (Hvězdy nad Baltimore, Stars over Baltimore, Palubní denik Zikmunda a Hanzelky, Zikmund and Hanzelka’s Logbook) and a formally very loose dramatic form, the stage libretto inspired by postwar events (Porta Apostolorum). We believe that this approach will best help to present the broad range of docudramas about the Czech past, both in all their thematic variety (the occupation, expulsion and normalization) and in their heterogeneity of form (analytical play, tribunal drama and the like). ${ }^{12}$

Before we proceed to the actual analysis of the selected dramas, we first need to consider the two key aspects of the issue. In the given context it is primarily necessary to clarify the relations between the docudrama and the historical play genre, as these are mutually permeable genre categories with a broad overlap. This can only be done because each of them is based on a different principle-the historical drama is a thematic genre, whose basic material is historical, whereas the docudrama is a formally-based genre, which includes-to a substantial extent and in various ways-material of a documentary nature within its own structure (mostly direct quotations of written historical sources). For this reason, too, biographical plays written from the contemporary perspective of authors from a generation that could not itself have lived through the events depicted, can be described as historical dramas that work with documentary techniques. Hence, these are historical plays of a documentary nature. On the other hand, one should bear in mind that not all historical plays can automatically be classified under the docudrama genre, just as documentary, authentication procedures are not just restricted to plays that deal with historical material.

Another aspect that is worth mentioning at this point is the actual character of the dramatic text as such. Based on the premise that a drama is a distinct literary genre, its uniqueness consists in the dual nature of its existence-on the one hand, as a literary work intended for reading, but on the other hand, in contrast

gative by nature, referring to a social dimension within which it employs anti-illusive and montage dramatic devices" (Jungmannová 36).

12 We are aware that our selection of plays to be analysed is by necessity reductive, but it is not possible within the space of a short study to present a comprehensive picture of any phenomenon, let alone a phenomenon that is as multiaspectual as the contemporary documentary drama. Hence, our study focuses on the selected types, which are meant to illustrate the basic developmental trends that docudramas follow. 
to the lyric and the epic, it is potentially also meant to serve as the basis for theatre productions. This study focuses on drama primarily as a literary work, while only taking a marginal interest in the theatrical context, i.e. the actual stage production(s). In the case of such texts as Bambuška's Porta Apostolorum, however, these are clearly not standard classic dramas for reading, but dramatic texts to be used primarily as instructions by stage directors, on the assumption that they would only be completed on stage. Taking this into account, we can ultimately divide the dramatic texts analysed here into two groups: plays in the literary sense, e.g. Zázrak v černém domě (Miracle at the Black House), which were adapted for book publication and whose existence is not just limited to one specific theatre performance, but also anticipates the possibility that they may become part of the theatre repertoire on several stages at the same time. And then there are texts that have never come out in book form, and are so closely associated with a particular theatre ensemble that it is practically impossible to consider their potential transfer to another stage. It turns out that in their case the documentary elements got into the texts in a much easier and more flexible way than in the case of regular dramas-these are not neglected in this study, primarily in order to show that the documentary "wave" has had a strong effect on dramatic texts in all their forms, and that in this respect it is of no substantial importance whether a text is intended more (or exclusively) for the internal needs of the production team or is freely available to the broader reading community. ${ }^{13}$

\section{Miracle at the Black House: Personal Memory as a Documentary Record of the Period}

Milan Uhde's play Zázrak v černém domě (Miracle at the Black House, published 2005, premiered 2007) represents a dramatic line that is based on the author's own unmediated life experience. ${ }^{14}$ In this, it basically differs from the majority of present-day documentary-based dramas, whose authors were not and could

13 It might also be possible, of course, to look at the issue of the documentary element from the opposite perspective, i.e. from the standpoint of theatre productions, and to consider the critical response or to examine the direction procedures, artistic stage designs and the like. However, this would undoubtedly lead us far away from the sphere of literature and thus from dramatic texts as literary creations, which we are primarily dealing with here.

14 Moreover, the authenticity of the text in the Brno staging of the play (premiered 2018) was supported by the use of a short film from Uhde's family archive, which is shown to the audience right at the beginning of the entire performance. Uhde had earlier 
not have been direct participants or contemporary witnesses of the events dealt with in their plays. Hence, Uhde's autobiographically conceived drama proceeds along two traditional genre lines: a) tying in with post-1989 drama on life under Communist (and Nazi) totalitarianism, and b) reviving the "analytical drama" genre made famous by Ibsen in his plays from the late nineteenth century and the early twentieth century. The documentary (in the true sense) nature of the text is thus minimal in this case, involving the story (inspired by real life) of one family, who after years of rowing meet up in the family house, so its members can try to iron out some ancient injustices and clarify their property relations - primarily regarding the issue of inheriting the family home. We can primarily follow the biographical elements in the drama in the character of Dušan, a former dissident and minister, who arrives together with his wife in order to come to an agreement over the inheritance of the functionalist villa for his mentally ill sister Śárka and to settle his long-troubled relations with his father, who during the normalization period had preferred to disinherit Dušan, as well as with his brother Ivan, who informed on him under the previous regime. Hence, the text of the play embodies the memory of one family clan that acts as a kind of synecdoche of twentieth century Czech history. Furthermore, history is also directly embodied in the text in the guise of the black house, which plays an active role in the play, as it acts symbolically at certain times-twice it tries to flood its own premises with water or suddenly opens the doors of wardrobes that for years have not been possible to unlock, surprisingly revealing that they do not conceal the entrance to a secret room, where family legend has it, their uncle was supposed to have hidden away from the transport to the concentration camp. Moreover, Miracle at the Black House clearly highlights the dividing lines between "us and them," which pass directly through the centre of the middle-class Pompe family-with Dušan standing on the ideological axis as a representative of the dissident, contrasting with his brother Ivan who is a collaborator with the previous regime. However, the text also highlights the ethnic axis in the case of the father, who compelled his wife to renounce her own Jewish-heritage parents during the Nazi occupation for fear of losing his property. Characteristically, all the family traumas and mutual injustices that were never subsequently followed by an effective apology or atonement are something that prevents the family from living a normal life, as can apply to Czech society as a whole, which the author believes in many respects has not come to terms with the legacy of two consecutive totalitarian eras.

provided a dramatic treatment of his own family history in the radio play Velice tiché Ave (Very Quiet Ave, manuscript 1981, premiered 1990). 


\section{Olga: A Portrait of the Great Wife of a Famous Man}

A biographically conceived narrative, albeit in this case not drawing from the author's personal memory, is offered by Anna Saavedra's play Olga (Horrory z Hrádečku), (Olga, Horror Stories from Hrádeček, premiered 2016), ${ }^{15}$ who, as in the case, for example, of Velvet Havel (premiered and published 2014) by Miloš Orson Štědroň and Havel v zemi čeledinů (Havel in the Land of the Stable Boys, premiered 2015) by Martin Františák, deals with the life of this icon of Czech dissent and the first post-revolutionary President, Václav Havel. Unlike most plays about Václav Havel, however, Olga focuses primarily upon Havel's life partner and first wife Olga, whereas Václav Havel himself is only assigned a place as one of the secondary characters in the play. However, Olga's life is naturally so intertwined with the fortunes of her life partner that even here scenes are played out that went down in history with a capital $\mathrm{H}$, such as the one about the President's short trousers. On the other hand, however, the figure of the prominent statesman in the text plays more of an auxiliary role, when at the same time (as the text prescribes) he is to be played by some three actors so as to clearly and much more obviously highlight Olga's difficult life role as the wife of the persecuted dissident. The documentary elements in the text get into the very dialogues-for example, some of the rejoinders involve recognized variations on Havel's Letters to Olga ${ }^{16}$ The play also includes references to film documentaries (e.g. The Hrádeček Phenomenon, or: Ghosts Beneath Břečtejn, a documentary directed by Andrej Krob) and magazine interviews (e.g. an interview with Olga Stankovičová from Revolver revue) and the like. In this way the entire testimony, otherwise clearly theatrical and self-avowedly fictional, with the actors alternating in roles as need dictates, is seemingly made credible and realistic. As a result, Olga is ultimately a fictional testimony about a real woman and in a general sense the testimony of a person who stood in the shadow of her husband all the while, but who in many respects rose above him in human terms, and if it had not been for her, Václav Havel would never have become what he finally came to be.

15 We are working with a previously unpublished text provided by the creator of this production.

16 References to sources are given in the text, as they are in specialist texts and footnotes, which is another of the features that underline the authenticity of the entire testimony: "But I am even less afraid of sci-fi phenomena; some animals, a marten, badger or the like-if they suddenly launch into dialogue with me then I am ill at ease ..." (Saavedra 10). 


\section{Verra: The Spiritual Path of a Hero Tested by Fate}

Verra (premiered 2018) ${ }^{17}$ by Simona Petrů is another of these biographically-based dramas; it endeavours to present the life and character of the once world-famous and exceptionally successful Czech athlete and gymnast Verra Čáslavská. Here, too, reality combines with fiction, and facts combine with "author's licence" in a very specific way. ${ }^{18}$ The key principle is pithily expressed in the author's declaration revealing her detachment from a biographical and thus historiographical role:

I'd rather leave biographies to historians and documentarists, that is, to those who are more competent, educated and, ideally in my view, objective. If I write a play about living individuals, then I use their life as a more general metaphor for a subject that I want to deal with. And just as when I am writing, it is my desire to present and defend their attitudes, so likewise it is my desire to present and defend my own view of things. I do not want to, and cannot, be impartial, but I just point out my own angle. (Vèra production programme 10)

This acknowledged selectivity and subjectivity in her view of the real Verra Č́slavská is conspicuously reflected in her focus on the mental state (and development) of the character, which in relation to the reality is by its very nature an unverifiable phenomenon that is scarcely demonstrable from a documentary standpoint. This is not a case of the complex psychologizing that we know from traditional realist-psychological dramas, but attention is focused primarily on the protagonist's "inner" resources and the positive qualities behind all her thinking and actions. In line with the author's ambition to set out inspiring national models, ${ }^{19}$ here we find characteristics that are highlighted

17 We are working with a previously unpublished text provided by the creator of this production.

18 This is immediately evident from a glance at the dramatis personae: apart from the female protagonist, real names are also borne by her colleague (Eva Bosáková), husband (Josef Odložil) and children (Martin and Radka Odložilová), as well as the presidents that Vera comes into contact with (Ludvík Svoboda and Václav Havel), while on the other hand generalizations are used in the case of the main competitor (the Soviet gymnast), the trainers (Male Trainer and Female Trainer) and other secondary characters (Journalist, Agent, Chairman, Man in Crowd, Woman in Crowd, and likewise Japanese Master and Old Samurai).

19 See her statement: "And again it is important for me to recall, to continually recall such figures from our nation. We have someone and something to be proud of, we 
in a quite schematic and almost hagiographic manner, such as the ambition, uprightness, persistence and dedication that Verra possesses to an extraordinary degree. Although all these virtues could "only" be demonstrated by presenting the specific situations and historical moments that Čáslavská lived through (e.g. signing the 2000 Words Manifesto in 1968 and her silent protest against the occupation of Czechoslovakia on the Olympic medal-winners' podium in Mexico, refusal to collaborate with the Communist regime and the like), the author also chooses a rather more "literary" method, i.e. a comparison of and confrontation between Čáslavskás CV and the traditional Japanese teaching of Samurai philosophy. This authorial gesture, whose logic is based on the real popularity that endures to this day of the three-time winner at the Winter Olympic Games in Tokyo 1964, as well as on her appreciation for this culture, enables her to productively and (within the docudrama context) uniquely comment on important events in the gymnast's turbulent life and in Czech history through the prism of a coherent and firmly anchored concept (the chief source of inspiration, which is even quoted in the play's motto, is Taira Shigesuke's Bushido: The Code of the Samurai). For the Czech (and Central European) reader this approach is made attractive not only thanks to its cultural exoticness, but also due to its ethical universality: it shows the protagonist to be a woman setting

have someone to relate to, we have these figures of admirable greatness, and we need not keep crying over our lot as small and subjugated. It is enough not to forget those who show us great ideals, great gestures and above all great actions" (Verra production programme 26). Likewise, the text of Tichý Tarzan (zcizené deníky fantoma erotické fotografie) (Quiet Tarzan (Stolen diaries from the phantom of erotic photography)) is a biographically based play by this author (premiered 2012, published. 2014) on the life of photographer Miroslav Tichý. Moreover, this play also makes a fine demonstration of links between fiction and reality as it takes place in a court, while the presentation of the text at the Divadlo Husa na provázku in Brno was judicially challenged by Tichýs neighbour and former housekeeper." Tichý's former neighbour and housekeeper Jana Hebnarová, presented in the play as the woman next door (played by Gabriela Štefanová), demanded that some parts of the production with the subtitle "Stolen diaries from the phantom of erotic photography" should disappear from the work. There are certain passages in it that directly describe his neighbour in a quite brutal manner, so she defended herself with an action for the protection of personal rights, confirmed Hebnarovás lawyer František Vyskočil. Hebnarová took offence at scenes in which as one of the characters in the play she has affairs with another key figure in Tichýs life, Swiss-Czech Roman Buxbaum (the Curator in the production-Vladimír Hauser), who made the photographer famous worldwide (see Pokorný). 
out on the path of personal growth from a Samurai novice to a grandmaster. ${ }^{20}$ Fateful blows both to her personally and to society as a whole (the occupation, denial of training opportunities, alcoholism and the aggression of a husband who reproached Vera for her pertinacity, as well as her son's patricide) can thus be seen not as the cruel chance of this world, but as tests to verify the extent of the protagonist's understanding and assimilation of these oriental doctrines. ${ }^{21}$

\section{Horáková vs. Gottwald: The Staging of this Show Trial as an Indictment Against the Past}

Another set of texts that we aim to deal with is a special genre called the tribunal drama, i.e. texts offering a fictional (re)construction of a real trial or similar proceedings. Karel Steigerwald's play Horáková-Gottwald (premiered 2006, published 2007) is based on the theatre within the theatre principle, working with the epic approaches that we know from Brecht's plays. In the text the past is brought back to life by means of a deliberately staged theatrical image, whereby the drama highlights the theatrical nature of the Communist-manipulated trial, ${ }^{22}$

20 Processuality is also evoked compositionally when, instead of individual images, the designation "Level" is used a total of fourteen times in the play.

21 A biographically-based play on an often extraordinary female chief protagonist that is comparable to a large extent is Vitka (published and premiered 2018) by Kateřina Tučková. The prototype for this titular heroine is Vítězslava Kaprálová, a world-famous composer and conductor, who died young. Amongst others, she was a friend and pupil of the famous Czech composer Bohuslav Martinů. Even in this traditionally structured drama, historical authenticity is evoked by a number of thematic and formal devices, such as the use of the entire names of real-life historical figures, the precise dating of some images and the factually-based author's introduction, which is relatively extensive for book production from 2018, as well as an expert postscript by musicologist Miloš Štědroň, a bibliography and an illustrated supplement showing the real-life counterparts of the dramatis personae. Paradoxically, the "authenticity" of the play is, alas, not based on a direct examination of the sources and primary sources, but on detailed research into the extensive secondary specialist literature and a literary version of Kaprálovás fate written by her former husband Jiří Mucha, as well as a novelized version by Jindřich Uher.

22 We can also find a similar approach in a play by Jan Jirků and Adéla Balzerová Vajgl (Fag End, 2010), which centres around the prisoners' uprising in Bory jail in the 1950s. "The historical level of the trial intermeshes with the fictional level in several places and motifs, time loses its linearity (so the outcome is anticipated), and time loops provide an insight into the absurdity of developments at that time" (Ljubková 16). 
the direction of this play within a play being taken on by Emil, described as an entertainer and an artist, intended to be the fictional counterpart of director Emil František Burian, who wrote his own notorious drama about the Milada Horáková trial Pařeniště (Hothouse). This revue-style play does not present the story in a linear fashion, but the syuzhet jumps about from one time level to another, until it finally comes to the anticipated conclusion, the moment of Milada Horákovás execution, which Emil thought would be just "make-believe" like at the theatre. Hence, the text is a clear indictment of the previous regime, particularly the 1950 s show trial period, in which a number of pro-regime artists were also involved, at least at a moral level. The actual inclusion of the sources and other period documentary records in the text is very precisely characterized by Lenka Jungmannová in her book $V$ souradnicích mnohosti (Within the Coordinates of Abundance):

Steigerwald chose a collage form for his testimony, including in the text not only the imprints of authentic events (although he replaced some historical facts with fictions, e.g. in contrast to the reality, Burian shoots himself here), but also documentary records in the form of songs (Stalin's favourite Sulika, Burian's songs Má panna je v Panama sama (My Love is Alone in Panama) and Magnetová hora (Magnetic Mountain), the Soviet battle song Svatá válka (Holy War) - Vstavai strana ogromnaya, etc.), poetry (Nezval's Zpěv míru, Song of Peace), newspaper article snippets, samples from Burian's play Pařeniště (Hothouse) and excerpts from Horákovás actual defence speech. In the notes the author also requires a recording of an authentic radio speech made by Lenin in 1919 and a radio recording of the verdict being read out from the trial in question. (qtd. in Fialová 714-715)

Using the theatre within a theatre technique, the Horáková vs. Gottwald stage revue reconstructs and interprets a now clearly petrified image of the past, in which the heroes of the anti-Communist resistance, personified here in the figure of Milada Horáková, stand against the comically caricatured lackeys of evil, who like grinning clowns "revolve around history," sowing discord. Hence, in the very title the hero has her obvious counterpart, who is truly antagonistic, in the figure of former President Klement Gottwald, who ultimately comes to be her murderer. 


\section{With and Without Hope: Painful Personal Reminiscences Evoked Ex Post}

Another of these "tribunal dramas" is a play by Tomáš Vůjtek $S$ nadějí i bez ní (With and Without Hope, published 2009, premiered 2012). ${ }^{23}$ It is somewhat in the nature of a commemorative cabaret, where selected passages from the life of Josefa Slánská, wife of the Czechoslovak Communist politician who was executed following the Moscow-directed show trials in the 1950s, are played out before the audience within the formal framework of a police investigation. Hence, this drama also deals with the inevitable Czech (Central European) conflict between "us and them," which in this particular case is made especially ironic by the obviously expedient and absurd fact that Rudolf Slánský and Josefa Slánská, who were persecuted by the Communists, had been stalwart supporters of Communism for several years at the time. It is historically based upon Josefa Slánskás memoirs Zpráva o mém muži, (Report on my Husband) and a set of interviews with Karel Bartošek Český vězeň (Czech Prisoner) and the book Proces s vedením protistátního spikleneckého centra v čele s Rudolfem Slánským (The Trial of the Anti-state Conspiracy Centre Headed by Rudolf Slánský). Additionally, the play includes quotations from the period press and literature. In his introductory note the author says that: "The quotations are as literal as possible, so that the chief protagonists' utterances retain their ideational authenticity to the greatest possible extent" (Ljubková 561). On the other hand, we should not overlook the fact that in some of his choices he veers distinctly away from strictly documentary procedures (apart from work with factographical material and literal quotations, the real life dates and names of historical figures and the like are often used), thus making Josefa Slánskás biography to a large extent literary and theatrical, specifically, for example, by not giving the chief protagonist the name of her antecedent in real life, but the universal She (her real name only occurs in responses that the protagonist herself gives to her interrogators), just as all the other roles are only embodied in two other dramatis personae designated First and Second, who are flexible

23 The author inclines towards biographical dramatic forms in a number of his other plays, such as Slyšeni (Hearing, premiered 2015), where using the tribunal formatwith a staged court trial actualizing the past and the psychological make-up of the chief protagonist, in this case the man behind the Nazi genocide Adolf Eichmann; Vujitek's other plays about notable figures in Czech history, using authentic materials to a substantial extent, include Spolu (Together, premiered 2015), Škoda! (Pity! premiered 2015) and Slávek Novák aneb Př́běh opravdového herce (Slávek Novák, or: A Tale of a True Actor, premiered 2018). 
onstage. The anti-illusory nature of the dramatic text, which can thus be understood as a kind of complement to its documentary nature, is underlined by the frequently used epic approaches, often presented by the two idiosyncratic co-narrators and commentators on the action, who basically adopt the role of "omniscient," sadistically malicious Communist inquisitors, as well as occasionally representing Rudolf Slánský, Klement Gottwald and other episodic characters in the play. ${ }^{24}$ The same effect is also provided by the play's paratheatrical nature: in front of the audience a specific trial with the chief protagonist is being played out, in which on the basis of the original memoir and other documentary records they reconstruct (renarrate and record) the decisive moments in her life, and by extension in the life of her family. In spite of this framework, however, Josefa Slánskás fortunes are only objectivized to a relative degree, and we still look at them through the protagonist's eyes, or in some places even as if in a dream, beyond reality.

\section{Stars Above Baltimore: A Collage Rehabilitating a Previously Proscribed King of Comedians}

Another-particular-type of documentary drama involves texts that work in a more focused manner with the (originally artistic) collage or montage technique. Clearly, the montage of motivational elements in the broader sense basically occurs in all docudramas that integrate historically authentic material into their structure one way or another. However, another part of the study focuses on a narrower set, i.e. on those cases in which montage (or collage) techniques become a prominent, indeed a decisive factor in the construction of the play and by extension in its aesthetic effect. Again, we shall select biographically-based plays as examples from the most recent dramatic output to represent this field, specificially Hvězdy nad Baltimore (Stars Above Baltimore)

24 The function of First and Second is aptly named by Ljubková: "First and Second present Her with Her fate in life: first they begin to read it (and She comments on it), then even perform it in front of Her. Hence, the interrogation is just a kind of starting point for the situation which then broadly develops. The staccato interrogation merges with the narrative epic passages; hence, the author transfers the role of the (unknowing) interrogators onto the recipients, because the assumed investigators know the story, move it on, and help Her, as they are more like guides to Her fate, seconds who turn into characters in Her life story. Sometimes, Her memories literally take Her along, and she has to appropriate them again. They see further, and they even admonish:

"Karel, don’t jump the gun" (Ljubková 20-21). 
by Luboš Balák and Palubní deník Zikmunda a Hanzelky (Zikmund and Hanzelka’s Logbook) by Vladimír Fekar.

Hvězdy nad Baltimore (published and premiered 2004) shows how it happened that just after the Second World War the much-loved interwar "king of comedians" Vlasta Burian turned into an outcast who brought down on himself total social condemnation and disgrace (after the Second World War the Communists confiscated Burian's assets, only allowed him to perform menial manual jobs, forbade him to make public performances and so forth). This story clearly depicts how the postwar social and political polarity reversal, so common in Central Europe, was able to bring about the as yet incomplete settlement of collective and personal accounts, as well as crushing reprisals; at a general level it is not just the comedian's abrupt fall from social grace that is highlighted, but also the way human envy of the gifted and successful individual can turn so easily and quickly into spiteful and inflammatory aggression-all it needs is that shift in the fulcrum of power, while the author displays his familiarity with the period context, as well as a detailed knowledge of Burian's professional and private life, undoubtedly assisted in creating the play by the already extensive, well-written secondary literature, particularly a monograph on Burian by Vladimír Just, who on the basis of a detailed study, description and new interpretation of archive material made substantial efforts to clear Burian's stigmatized name prior to $1989 .{ }^{25}$ The rehabilitation of Burian, who was repeatedly accused of pro-Nazi collaboration, is also attempted in a way by Balák. While following this rather "non-artistic" objective, the author does not launch into dryly objective evidence-gathering, but quite the reverse, he seems to use such strictly "exact" techniques with considerable restraint: even though the situations and dialogues that he integrates into the play are generally plausible, in the stylization that Balák offers it is obvious that in this form they cannot not be invented or to a large extent speculated over. Characteristically for a docudrama (or tribunal/verbatim drama), it includes the normally audience-friendly "figure" of a judicial investigation or trial, but even here no attempt is made at maximally realistic (literal and conforming to protocol) actualization of court cases, but rather a focused vivid recapitulation of the main arguments on both sides (the investigating judges responding to society's demands and the political pressure versus Vlasta Burian and his faithful wife Nina, defending themselves and explaining away the serious accusations). As befits the Communist regime, the proceedings are properly prepared, while the main points recur in a varied manner; hence, the course of Burian's trial is to a large extent just 
a formality, a kind of ostentatious arm-wrestling that has been fixed in advance. The method of fragmentary and not entirely linear treatment of the material using the "selected chapters" technique loosens the structure (of what is regular), but thereby actually tends to strengthen the fictional "concept of authenticity." Hence, Burian's life drama does not strive for catharsis or a surprising punchline, as in a number of other documentary plays. Provided they are not built in an explicitly contrafactual manner, the basis of their message or their overall effect is not a convincing or definitive answer to the question "how did it turn out?", but rather a quest for how the events (probably) took place and how those affected perceived and experienced them.

\section{Zikmund and Hanzelka's Logbook: A Historical-Biographical Set}

Another biographical play Palubní deník Zikmunda a Hanzelky (Zikmund and Hanzelka's Logbook, published 2012, premiered 2013) also makes substantial use of historical material, presenting successful and generally popular figures from twentieth century Czech history, as in the case of Hvězdy nad Baltimore (as well as Verra and other plays), while the text is remarkable for its even greater compositional looseness than that of Balák's play; again we might refer to a stage collage, or even a kind of set with motifs from the lives of real-life historical figures, stringing together records from the travellers' expeditions in formal dialogue form, articles from the period press, as well as words from other period media (particularly film weeklies and radio): ${ }^{26}$

Zikmund 2: The world need not only be seen from behind a car windscreen, but also, for example,...

Zikmund 1: From on top of a pyramid ...

Music, arrival of a pyramid. The god RA on top, still in nocturnal form.

Projection of the pyramid in the background.

Hanzelka 1: At 19.40 the ascent commenced.

Zikmund 1: Then came night.

Hanzelka 1: Our night on the pyramid.

Zikmund 1: Within a few hours the fascinating theatre beneath the pyramid had completely changed. The garlands of lights over Cairo

26 Again the author's clear statement is inserted in the dramatic text: “The text includes or paraphrases quotations from correspondence, travel diary entries, the travellers' testimonies in television documentaries, speeches, forums and other available material" (Ljubková 527). 
had thinned out, as the red glow of Bedouin fires turned into fading sparks.

Hanzelka 1: The stirring melody of Arabic song faded and the distant howls of jackals grew quiet.

Zikmund 1: Somewhere in the distance the roar of aircraft engines could be heard. A dark shadow floated up to the Great Pyramid and immediately swung over its apex, slowly disappearing into the distance, interspersed by the blinking of red and white will0 '-the-wisps merging in with the stars.

Hanzelka 1: Only the occasional flurry of bats' wings disturbed the deep silence of the night. (Ljubková 541)

Clearly, here too it is not the author's ambition to create a coherent, regular dramatic structure, but rather the suggestivity of authentic experiences, as embodied in period documentary records, that are meant to be preserved. Although it is not only real-life figures, who demonstrably met or at least might theoretically have met, who interact here, but also entirely literary figures (apart from older and younger versions of the protagonists, the dialogue also includes, for example, the Angel and the Devil, Czechoslovakia personified, the Egyptian god RA, a choir and others), it is clear that even at the risk of weakening the dramatic effect the author attempts to honour well-known and less well-known facts about the lives of these popular travellers, or to be more precise, despite some fantasy and clearly invented elements, he does not want to get into a conflict with these facts. History literally jumps at the feet of the protagonists and holds back their ascent even in this play. As a result of the Nazis closing higher education establishments, their commercial engineering course is postponed for quite some time, and the adventurers have to literally wrest their first journey from the authorities through sheer obstinacy (going right up to Gottwald himself, whom they catch on the toilet); the protagonists are also compelled to agree to their books being censored, and naturally enough their incisive, critical analysis of conditions in the Soviet Union does not go down well in Communist circles, particularly since they present it as non-party members and so forth. However, the watershed moment is the Prague Spring, when both travellers became politically engaged to such an extent that one of them was considered as a presidential candidate. But then all that was cut short by the invasion of the Warsaw Pact armies, which is an anticipated moment within the context of the play, as Hanzelka's and Zikmund's protest against the occupation is prefigured in the prologue. A record is also made of the subsequent liaison between the now persecuted travellers and dissident Ludvík Vaculík, who published 
another of their books in a minimum print-run in his samizdat series, when they were officially proscribed, after which the careers of the travelling partners are followed in the epilogue up to Jiří Hanzelka's death in 2003.

To summarize, here we again see the inevitable structure of numerous Czech biographical documentary plays on figures who lived (chiefly) in the twentieth century, particularly those who willingly or unwillingly came into conflict with one of the totalitarian regimes in Central Europe during this period: this structure, already observable previously in Věra and Hvězdy nad Baltimore, might be characterized as follows: success, celebrity; incurring the wrath of those in power; punishment, fall; (optional) partial rehabilitation and satisfaction (albeit sometimes "not in this world").

\section{Porta Apostolorum: Libretto on the Disorderly Postwar Expulsion}

The expulsion of the Sudeten Germans from Postoloprty in Northern Bohemia is the main subject in Miroslav Bambušek's dramatic text Porta Apostolorum (published 2004, premiered 2005). ${ }^{27}$ This play has a relatively loose format with a minimum of stage notes, so that it is sometimes quite difficult for the reader to follow the movement of the characters on the stage, to clearly distinguish individual dramatic situations and to differentiate the realist level from dreambased passages. Hence, instead of a firmly established stage project this text only offers raw material to be rounded off and completed onstage.

The play's structure is that of a collage, which speaks volumes about the unusual interpretational openness of the work. However, the author was also working with deconstruction techniques when he created the relatively heterogeneous syuzhet, comprising two intertwining plot lines, which ultimately emerge at a third level (including the view of the plot from a contemporary perspective). (Just qtd. in Fialová $679-680$ )

The overall situation on which the play is based is the eighteenth birthday celebrations of the son of a fairly wealthy German family taking place several weeks after the end of the war, to which the current mayor and other Czech neighbours are invited. The celebrations, which initially take place in a peaceful and amicable atmosphere, gradually turn into a ghastly event; however,

27 The subject of the postwar expulsion of the Germans also appeared, e.g. in a play by Jiři Havelka and Karel František Tománek: Dechovka (Brass Band, premiered 2013). 
due to the quantity of alcohol drunk, inter alia, the celebration culminates in murder in the final scene. The second plot line then presents a love triangle between the now adult Fritz, a German girl Kati and her persistent suitor Pavel. The atmosphere of lurking bloody revenge and slowly increasing horror imbue the play with elements of tension and mystery. The text is thus basically a clear indictment of Czech society for the massacre in June 1945, when some 800 German civilians lost their lives in Postoloprty. The play itself is introduced by an authentic report on the investigation into this mass murder by the Ministry of National Defence in $1947 .^{28}$ Unexpectedly, the play also includes quotations from Patrik Ouředník's Europeana, Lenin's Brief Biography and normalization period magazines (e.g. Pionýr). Moreoever, at several points during the awful game of Hitler, which the mayor plays with the German family, they recall the utterances of the former Nazi leader. The authenticity of the story, which does not actually reconstruct any real event, but metaphorically represents, actualizes and reinterprets the bloody postwar events, was then also underlined in Bambušek's plays by the fact that they include "a staged reading of reports from the investigating committee proceedings ... and a procession around the concealed, overgrown and unmarked locations of the greatest postwar mass murders in Bohemia ..." (Just qtd. in Fialová 679). On the other hand, because the author does not work with particular historical figures in the text, the play cannot be considered to be purely documentary, as here history only

"On April 25, 1947, a letter was delivered to the Ministry of National Defence, as was a letter with the same content on April 30 to the Interior Ministry, signed by Otto Osfald, Postellberg, Leninova ulice No. 1345/67, in which the writer referred tot the postrevolutionary events in Postellberg in May and June 1945. The same letter was also delivered to the Ministry of Justice, which sent a copy on May 27, 1947, to the Interior Ministry. On June 12, 1947, the Office of the President of the Republic sent a letter it had received to the Interior Ministry, referring to these events and signed by Marie Osfaldová in Postellberg, Stalinova ulice No. 342. As a result, the Ministry of National Defence preliminarily had the case investigated by its officer. On May 30, 1947, and June 17,1947, the Interior Ministry then ordered the regional State Security Office in Most to confidentially investigate the case with dispatch. According to a further report from this office dated August 25, 1947, both letter writers were anonymous, because the persons named were unknown at that location. No further, more detailed investigation was made, because a UMs Security Commission Investigation Committee had been established, and it was not desirable for the Committee investigation to be encumbered by a preliminary investigation by security or military bodies. Hence, the Ministry of National Defence and the Interior Ministry present this preliminary report on events in Postellberg om May and June 1945" (Bambušek 2). 
comes into the text as a source of inspiration, as the main thematic area which the author primarily took up for clearly ideological reasons, since his objective was to retroactively rehabilitate the victims of postwar violence. Hence, Porta Apostolorum presents a historical event recast as a unique fictional story. From this point of view, Bambušek's experimental text, if the extent of its documentary nature could somehow be measured, is about as "weakly" documentary as, for example, Uhde’s formally traditional Zázrak $v$ černém domè.

\section{Docudrama as a Way to Create Collective Memory}

Clearly, it is the ambition of docudrama creators to go substantially beyond the field of literary (dramatic) work, i.e. the aesthetic dimension. Moreover, any shift towards factuality considerably bolsters the persuasiveness of the depicted events and actions (or, in other words, invokes the impression of "authenticity," which is so often valued in art); hence, the persuasive function, as well as sometimes the educational function, is applied to a substantial extent in these works. The attention that is devoted in these plays to the issues surrounding the correctness or the reprehensibility of particular actions and behaviour as a whole has a considerable ethical dimension.

The authors of documentary plays in the Czech context, who regularly focus their attention on the recent or not so recent past, often wish to take an active part in forming social memory. In contrast to the generalizing and abstracting historiographical expositions, however, by the very nature of the matter, i.e. due to the nature of artistic creativity, they tend towards a concrete, subjective and inductive viewpoint. Whether they are presenting a conception that is pretty much in line with contemporary national historiography or actually revising it, and whether their intention and tone are "celebratory" or "demythologizing," 29 there is also always a particular reflection of society, a contribution that co-creates its collective consciousness and a sense of solidarity. This is also the reason why our exposition left out documentary-style political satires lampooning contemporary political representatives, such as the work of Iva Klestilová Standa má problém (Standa Has a Problem, published and premiered 2006) and Petr Čtvrtníček's Ivánku, kamaráde, můžeš mluvit? aneb To mi ho tedy vyndej (Ivan, Buddy, Can You Speak? Or: Take It Out For Me Then, premiered 2005, published. 2006), where the distance in time from what is depicted is currently still too short, even though this is potentially historical material. On the other hand, we

29 "Monumentalizing" or working with competing alternatives of the previous (mainstream) exposition of history (see Erll 249-276). 
have focused on relatively new and not publicly well-known controversial views of events and protagonists in twentieth century Czech history. In addition to describing the various documentary forms in dramatic texts, it has also been our aim to point out and present specific examples of theatre plays attempting in a more or less non-conformist manner to elucidate several episodes from Czech history and in numerous cases to also rehabilitate particular historical figures and thus also to profile the collective memory and Czech national identity, which is inseparable from the Central European cultural space.

Translated by Pat Mertova

\section{| References}

Primary SOURCES

Bambušek, Miroslav. Porta Apostolorum (unpublished).

Balák, Luboš. Hvězdy nad Baltimore. Hry na hrdiny. Ed. Marta Ljubková. Brno:

Větrné mlýny, 2014. 317-462.

Fekar, Vladimír. Palubní deník Zikmunda a Hanzelky. Hry na hrdiny. Ed. Marta

Ljubková. Brno: Větrné mlýny, 2014. 525-594.

Petrů, Simon. Věra (unpublished).

Saavedra, Anna. Olga - Horrory z Hrádečku (unpublished).

Steigerwald, Karel. "Horáková-Gottwald." Hry na hrdiny. Ed. Marta Ljubková.

Brno: Větrné mlýny, 2014. 215-258.

Uhde, Milan. Zázrak v černém domě: komedie o dvou dílech. Brno: Větrné mlýny pro občanské sdružení Centrum pro kulturu a společnost, 2012.

Vůjtek, Tomáš. "S nadějí i bez ní." Hry na hrdiny. Ed. Marta Ljubková. Brno:

Větrné mlýny 2014. 259-316.

SECONDARY SOURCES

Barthes, Roland. "Efekt reálného" Trans. Tomáš Jirsa. Aluze 3 (2006): 78-81.

Barton, Brian. Das Dokumentartheater. Stuttgart: Metzler, 1987.

Bartošek, Karel. Český vězeň: svědectví politických vězeňkyň a vězňů let padesátých, šedesátých a sedmdesátých. Prague: Paseka, 2001.

Erll, Astrid. "Literatur als Medium des kollektiven Gedächtnisse." Gedächtniskonzepte der Literaturwissenschaft. Theoretische Grundlegung und Anwendungsperspektiven. Eds. Asdrid Erll and A. Nünning. Berlín, 2005.

Fialová, Alena, ed. V souřadnicích mnohosti: česká literatura první dekády jednadvacátého století v souvislostech a interpretacích. Prague: Academia, 2014. 
Irmer, Thomas. "A Search for New Realities. Documentary Theatre in Germany." The Drama Review 3 (2006): 16-28.

Jungmannová, Lenka. Příběhy obyčejných šilenství: "nová vlna” české dramatiky po roce 1989. Prague: Filip Tomáš-Akropolis, 2014.

Just, Vladimír. Věc: Vlasta Burian. Díl 1. Prague: Rozmluvy, 1991.

---. Vlasta Burian: Mystérium smíchu: Život a dílo krále komiků. Prague: Academia, 1993.

Lopatka, Jan. Předpoklady tvorby. Prague: Československý spisovatel, 1991.

---. Šifra lidské existence. Prague: Torst, 1995.

Ljubková, Marta. "Za hrdiny se nestydíme.” Hry na hrdiny. Ed. Marta Ljubková. Brno: Větrné mlýny, 2014. 11-33

Malzacher, Florian, ed. Not Just a Mirror. Looking for the Political Theatre of Today. Berlin: Alexander Verlag, 2015.

Martin, Carol. "History and Politics on Stage. The Theatre of the Real." Not Just a Mirror. Looking for the Political Theatre of Today. Ed. Florian Malzacher. Berlin: Alexander Verlag, 2015. 32-43.

Martin, Carol. Theatre of the Real. Palgrave Macmillan, 2013.

Mucha, Jiří. Podivné lásky. Prague: Československý spisovatel, 1988.

Pokorný, Marek. “Tichý Tarzan před soud.” Divadelní noviny, 2015, https://tinyurl.com/y95mvdzu. Accessed 1 August 2019.

Proces s vedením protistátního spikleneckého centra $v$ čele s Rudolfem Slánským. Prague: Orbis, 1953.

Putna, Martin, C. Obrazy z kulturních dějin Střední Evropy. Prague: Vyšehrad, 2018.

Rupnik, Jacques. Střední Evropa je jako pták s očima vzadu: o české minulosti a prítomnosti. Prague: Novela bohemica, 2018.

Taira, Šigesuke. Bušidó: cesta samuraje. Adamov: Temple, 2002.

Trávníček, Jiří. V kleštích dějin: střední Evropa jako pojem a problém. Brno: Host, 2009.

Uher, Jindřich. Ona a Martinů. Prague: Sursum, Český spisovatel, 2002.

Ulrich, Jan. Úvod. Střední Evropa, Vol. 1, 1984.

Véra (program k inscenaci). Národní divadlo: Brno, 2018.

Vostrý, Jaroslav and Zuzana Sílová. České drama a český hrdina. Prague: AMU, Kant, 2017. 


\section{| Abstrakt}

Aleš Merenus, MareK LolloK

Obraz czeskiej przeszłości we współczesnych sztukach teatralnych typu „dokudrama"

Artykuł ma na celu uchwycenie, opis i analizę sposobów przenikania materiałów dokumentalnych do struktury, a tym samym również do świata fikcyjnego współczesnych tekstów dramatycznych. Na wybranych przykładach przedstawia kilka typów czeskiego „dokudramatu”, od sztuk o charakterze biograficznym, poprzez tzw. tribunal drama aż po kolaże sceniczne. Wspólnym mianownikiem tych tekstów jest zamiar autora, by wywołać u odbiorcy wrażenie autentyczności, celem zaś nowa interpretacja wydarzeń historycznych, ewentualnie przedstawienie lub rehabilitacja określonej postaci historycznej. Ambicją twórców jest kształtowanie na nowo pamięci zbiorowej i czeskiej tożsamości narodowej w obrębie środkowoeuropejskiej przestrzeni kulturowej.

Słowa kluczowe: sztuka teatralna; docudrama; tribunal drama; współczesny teatr czeski; tożsamość narodowa; Europa Środkowa

\section{| Abstract}

\section{Aleš Merenus, Marek Lollok}

\section{The Image of the Czech Past in the Contemporary Docudrama}

This study attempts to depict, describe and analyse the intersection of documentary material with the structure and, by extension, the fictional worlds of current drama texts. On the basis of selected examples, it presents several types of Czech docudrama, from biographically-based plays and "tribunal dramas" to stage collages. The common denominator behind these texts is their attempt to create an impression of authenticity among recipients, as well as "faithfulness" to reality. Their main objective is to provide a fresh interpretation of a historical event or to present or rehabilitate particular historical figures and, not least, also to recreate collective memory and the Czech national identity within the framework of the Central European cultural space.

Keywords: documentary drama (docudrama); tribunal drama; current Czech drama; national identity; Central Europe 


\section{| About the Authors}

Marek Lollok: Mgr., Ph.D., is a member of the Modern Czech Theatre Research Team at the Institute of Czech Literature of the Czech Academy of Sciences, 2oth Century and Contemporary Literature Department; he currently works as an assistant professor at the Masaryk University Faculty of Education, Czech Language and Literature Department in Brno. His particular areas of interest include literary and theatre criticism, 2oth century Czech drama and literary studies stylistics. For example, he has co-authored the collective monograph Czech in Motion (Minářová, E., Tušková, J.M. (eds.), Czech in Motion. Chapters on Research into its State and Changing Face. Brno: Masaryk University, 2015), and at present he is a member of a team working on a lexicographical project entitled Modern Czech Drama (1896-1989); Between the Text and the Production (Encyclopedia of Works).

E-mail: lollok@ucl.cas.cz

Aleš Merenus: Mgr., Ph.D., is head of the Modern Czech Theatre Research Team at the 2oth Century and Contemporary Literature Department within the Institute of Czech Literature of the Czech Academy of Sciences. His main research interests include theatre and drama theory, the theory of the dramatization of literary works, narratology, the theory of fictional worlds and 2oth century Czech prose and drama, and he has published several studies on these subjects, (e.g. Two drama texts and a planned stage director (2012), Much Ado About Heterocosmica, or: Several notes on the fictional worlds of theatre productions (2012); The Theatrical Anabasis of Hašek's Fateful Adventure, or: Every age requires its Švejk (2016); Emigrants, or: Seeking the soul of a nation in Blatny's drama (2017). He is currently compiling an anthology of expressionist plays entitled The Expressionist Play from the Czech Lands, and he is editor-in-chief of the forthcoming encyclopedia Modern Czech Drama (1896-1989); Between the Text and the Production (Encyclopedia of Works).

E-mail:merenus@ucl.cas.cz 
